\title{
A PRÁTICA DO TURISMO E A PRODUÇÃO DOS LUGARES: UM OLHAR SOBRE MACANETA - MOÇAMBIQUE
}

THE PRACTICE OF TOURISM AND THE PRODUCTION OF PLACES: A LOOK AT MACANETA - MOZAMBIQUE

\section{RESUMO}

Artigo produzido a partir de projeto desenvolvido em Moçambique. Apresenta apontamentos sobra a pratica turística em Marracuene, distrito de Maputo, com foco na produção do lugar turístico. A hipótese é que o turismo comunitário proporciona possibilidade de geração de trabalho e renda com o controle dos trabalhadores sobre as suas práticas. No concreto ocorre a subjugação do trabalho dos artesãos e pescadores na logica da mercantilização das práticas sociais dos moradores locais, essa realidade impõe apontar propostas de superação desse processo, com a identificação de sinais presentes nas práticas de produção comunitária.

Palavras-chave: Prática Turística; Lugar; Macaneta/Moçambique

\section{ABSTRACT}

Article produced from a project developed in Mozambique. It presents notes on the tourist practice in Marracuene, Maputo district, focusing on the production of the tourist place. The hypothesis is that community tourism offers the possibility of generating work and income by controlling workers over their practices. In particular, the work of artisans and fishermen is subjugated in the logic of commodifying the social practices of local residents, this reality calls for proposals to overcome this process, with the identification of signs present in community production practices.

Keywords: Tourist Practice; Place; Macaneta/ Mozambique.

\section{Edvaldo Cesar Moretti ${ }^{\text {a }}$}

${ }^{\text {a }}$ Universidade Federal da Grande Dourados (UFGD), Dourados, MS, Brasil

DOI: $10.12957 /$ geouerj.2020.53712

Correpondência: ecmoretti@hotmail.com

Recebido em: 13 set 2019

Revisado em: 07 abr 2020

Aceito em:15 mai 2020 


\section{INTRODUÇÃO}

Texto produzido a partir das diversas reflexões realizadas durante o projeto "Práticas sociais e saberes de mulheres e homens e a produção do território rural no Distrito de Marracuene em Moçambique: viabilidade das alternativas produtivas no mundo da sustentabilidade", desenvolvido no período de 2014 a 2018, com apoio da CAPES/AULP. O projeto foi realizado a partir de parceria entre grupos de pesquisa da Universidade Federal da Grande Dourados (UFGD) e grupo de pesquisa da Universidade Eduardo Mondlane de Moçambique, especificamente o Centro de Análises de Política (CAP), tal qual podemos observar suas instalações conforme figura 1:

Figura 1. Edifício do CAP/UEM - Maputo. Autor: MORETTI, E. C., 2016.

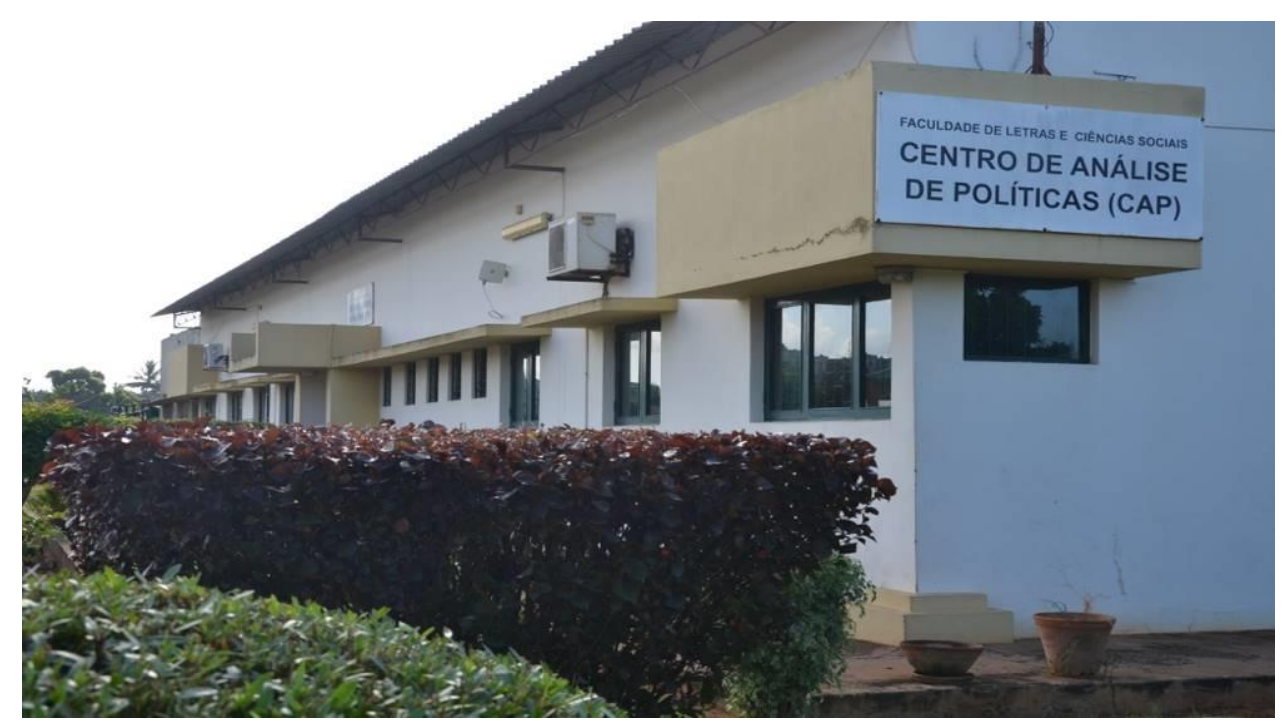

O principal objetivo do projeto foi analisar a produção do lugar turístico, na perspectiva da geração de trabalho e renda, bem como os aspectos que envolvem a permanência das famílias na terra. Para o alcance desse objetivo, a atividade turística é referência para as ações propostas em uma perspectiva do turismo comunitário, considerando fundamental pensar o processo de autogestão das práticas e a valorização das manifestações culturais:

\footnotetext{
[...] que se utiliza dos recursos naturais e culturais existentes nos lugares de forma sustentável, surge o turismo de base comunitária, o qual se diferencia do turismo convencional, chamado de massa, por priorizar a conservação do meio ambiente e das culturas tradicionais, e emergir como alternativa para que pequenas comunidades potencializem que seus modos de produção e de organização possam ser compreendidos como atrativos turísticos, sem que ocorra a espetacularização, mas sim oportunidades de trabalho e geração de renda para seus moradores. (SAMPAIO; ZAMIGNAN, 2011, p. 26).
}

A metodologia que alicerçou a pesquisa se constituiu por um caráter qualitativo, reflexivo e horizontal, e envolveu as reflexões intercambiadas por teorias, pela prática costumeira e por experiências multiculturais 
dos grupos e de pessoas envolvidos na pesquisa. Essa metodologia qualitativa é auto avaliativa e reflexiva porque é concebida como construção dialética propulsora da emergência de contradições da vida cotidiana, em caminhos sem definições objetivas e lineares, isso indica a complexidade dos fenômenos, "não sendo fácil separar causas e motivações isoladas e exclusivas" (MARTINS, 2004, p. 291).

O lugar a ser pesquisado foi definido em dialogo com a Coordenadora do projeto da Universidade Eduardo Mondlane de Moçambique. $O$ distrito de Marracuene foi entendido como adequado para realizarmos as atividades propostas pela equipe, considerando que é uma área com atividade rural expressiva, além da atividade turística já implantada na Praia de Macaneta, com pessoas que se dedicam a prática de atividades artesanais, como produção de utensílios, pesca bem como a proximidade com Maputo (cidade onde se localiza a Universidade Eduardo Mondlane). Nas figuras 2 e 3, é possível observar a localização de Marracuene e da Praia de Macaneta, já na figura 4 é possível observar as famílias dos pescadores ajudando a puxar a rede de pesca:

Figura 2. Localização de Marracuene e Praia de Macaneta em relação a Maputo. Fonte: Cenacarta-Moçambique.

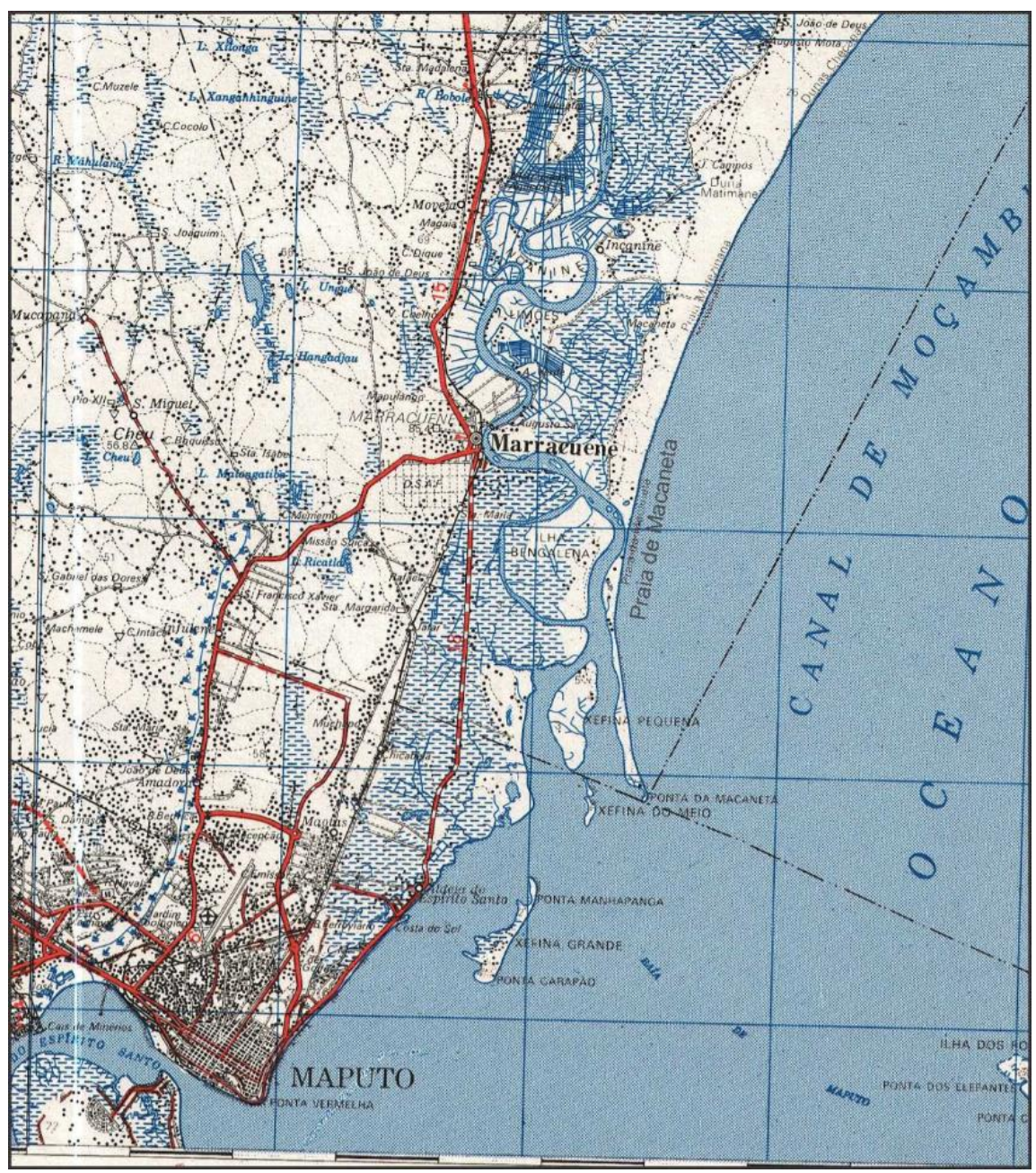


Figura 3. Posição da Praia de Macaneta em Marracuene. Fonte: Cenacarta-Moçambique.

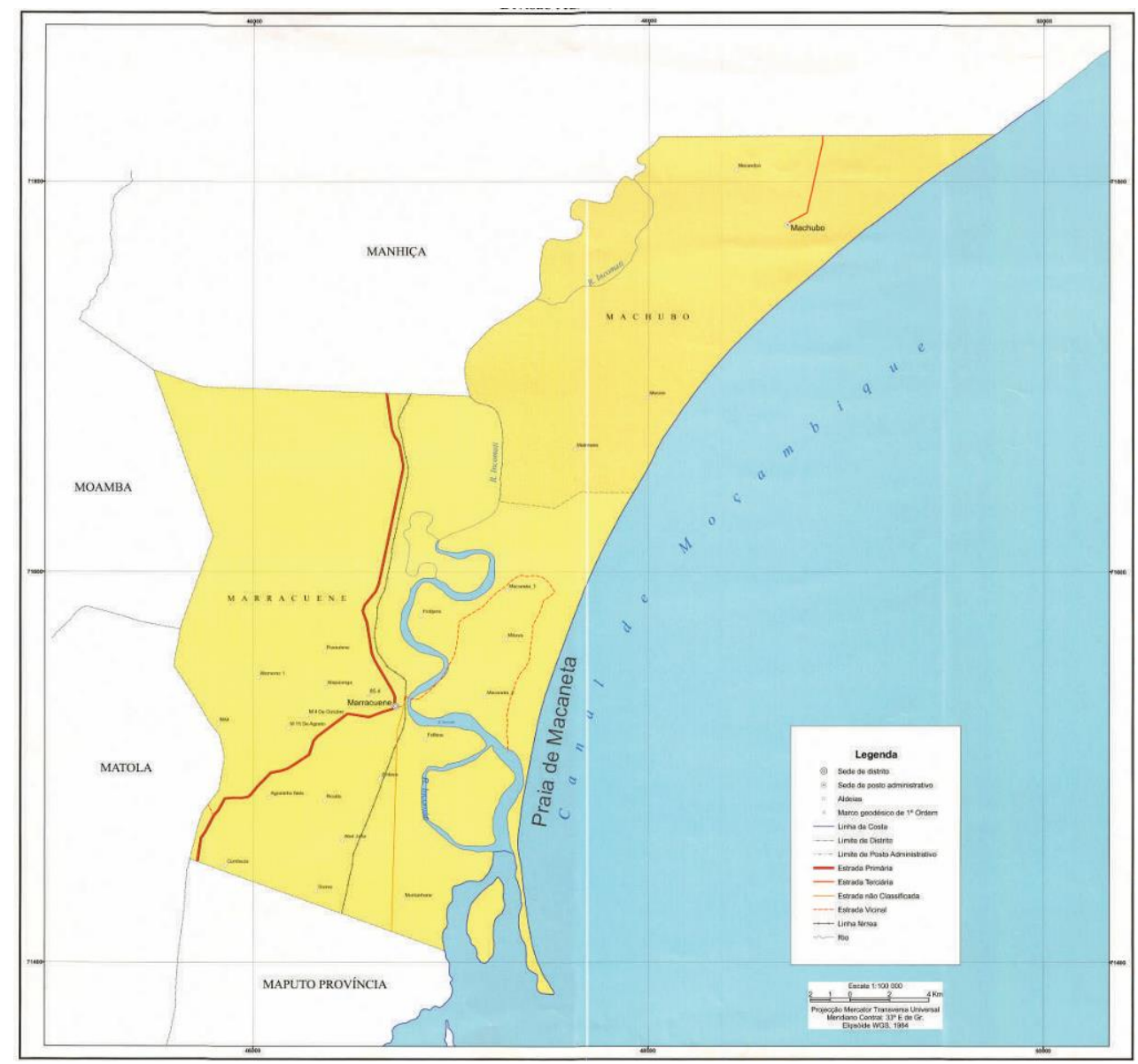

Figura 4. Praia de Macaneta. Autor: MORETTI, E. C., 2016.

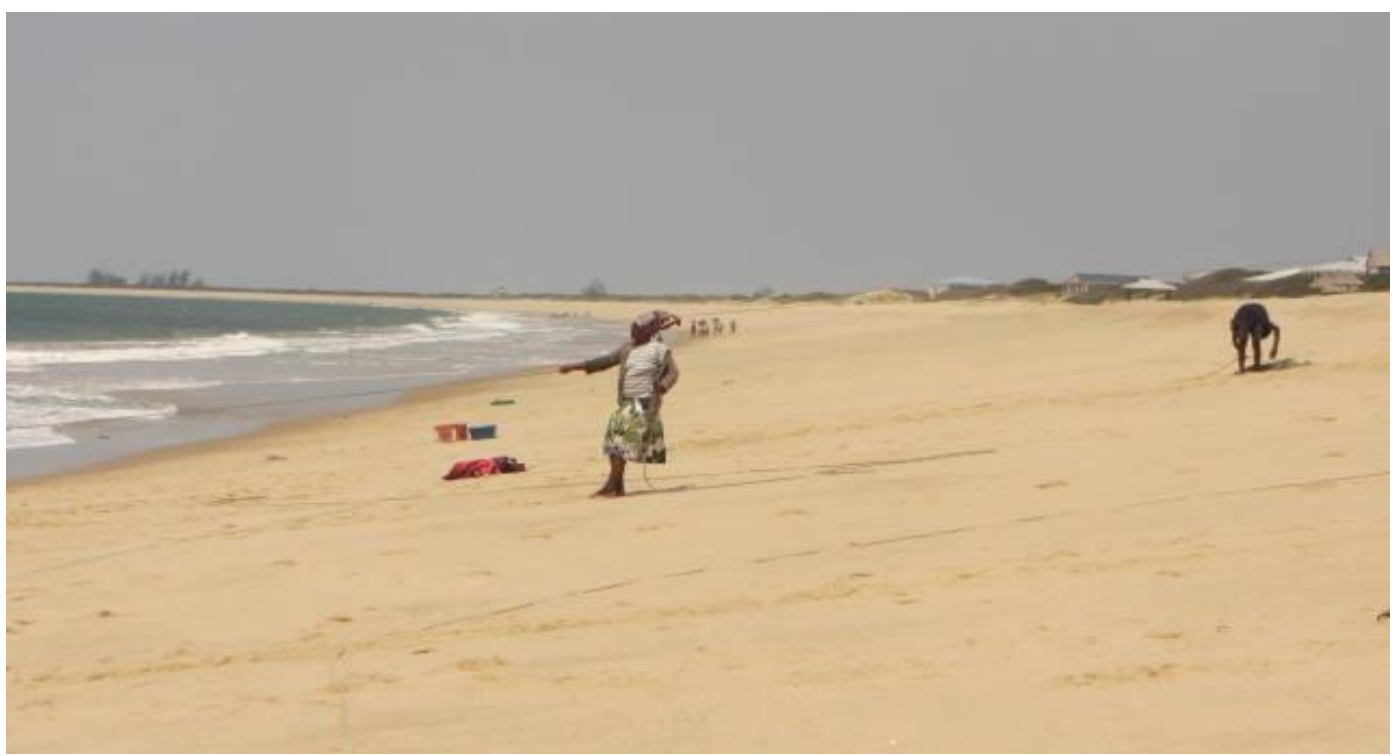


A partir da opção teórica e metodológica e a definição do lugar da pesquisa, definimos utilizar os preceitos do turismo comunitário orientado pela economia solidária, como hipótese para a geração de trabalho e renda com vistas à valorização do modo de vida das pessoas, considerando as características de seu cotidiano, sua história e memória de resistência, são pressupostos para a organização das atividades turísticas.

Para desenvolver a análise de tal realidade e perceber o potencial turístico de algumas comunidades, localizadas em Marracuene - Moçambique, foram considerados aspectos da vida cotidiana, tais como: as relações de gênero, o trabalho das mulheres, a presença das crianças nos espaços sociais, a interferência do turismo de/para o mercado, as transformações rurais e urbanas no território mediadas pelo mercado, os conflitos culturais.

Procuramos preliminarmente construir um panorama da participação da atividade turística em Moçambique, através do levantamento de dados junto ao Sindicato de Trabalhadores na Indústria do Turismo e do Ministério do Turismo.

O sindicato conta com 53.710 trabalhadores filiados, sendo que destes, 29.150 são homens e 24.560 são mulheres. São trabalhadores do circuito turístico de Moçambique, sendo constituído, sobretudo, por funcionários de hotéis e resort. No sindicato são 31.730 sócios e destes 12.440 são mulheres, assim constatamos que não há mulheres na direção do sindicato. De acordo com o presidente do sindicato o salário base da categoria é de 4.676 Meticais (moeda local). 0 salário médio, no entanto, gira em torno de 8.000 Meticais. Atualmente, as principais lutas da categoria estão pautadas na reivindicação de 90 dias de afastamento para gestantes, 13 을 salário, abono de férias e previdência social ${ }^{1}$. (Entrevista realizada com o presidente do Sindicato de Trabalhadores na Indústria do Turismo de Moçambique, 2016).

Outra entrevista relevante foi com o Secretário Nacional do Turismo, no Ministério do Turismo de Moçambique. Recebemos informações sobre os projetos para o desenvolvimento do turismo em Moçambique, destacando que os projetos visam a divulgação de lugares turísticos de Moçambique com destaque para o turismo de Praia e Mar.

A produção de lugares destinados ao turismo ocorre em parceria com empresas privadas internacionais, com destaque para empresas hoteleiras chinesas e sul-africanas. O poder publico realizou parcerias com empresas chinesas e efetivou empréstimos para a implantação de infraestruturas, principalmente obras relacionadas a construção de rodovias. Especificamente, para a área de pesquisa, duas obras chamam atenção: a construção da ponte sobre o Rio Incomati (figura 6) permitindo o acesso à praia de Macaneta, substituindo o transporte por balsa; a construção de rodovia Estrada Circular de Maputo (figura 5) que agilizou o acesso a

\footnotetext{
1 Dados obtidos através do junto ao Sindicato de Trabalhadores na Indústria do Turismo em pesquisa de campo em 2016.
} 
Marracuene, diminuindo o tempo de viagem dos turistas provenientes da África do Sul. Estas obras são realizadas pela empreiteira chinesa China Road \& Bridge Corporation (CRBC).

Figura 5. Obra para construção da Circular de Maputo. Autor: MORETTI, E. C., 2016.

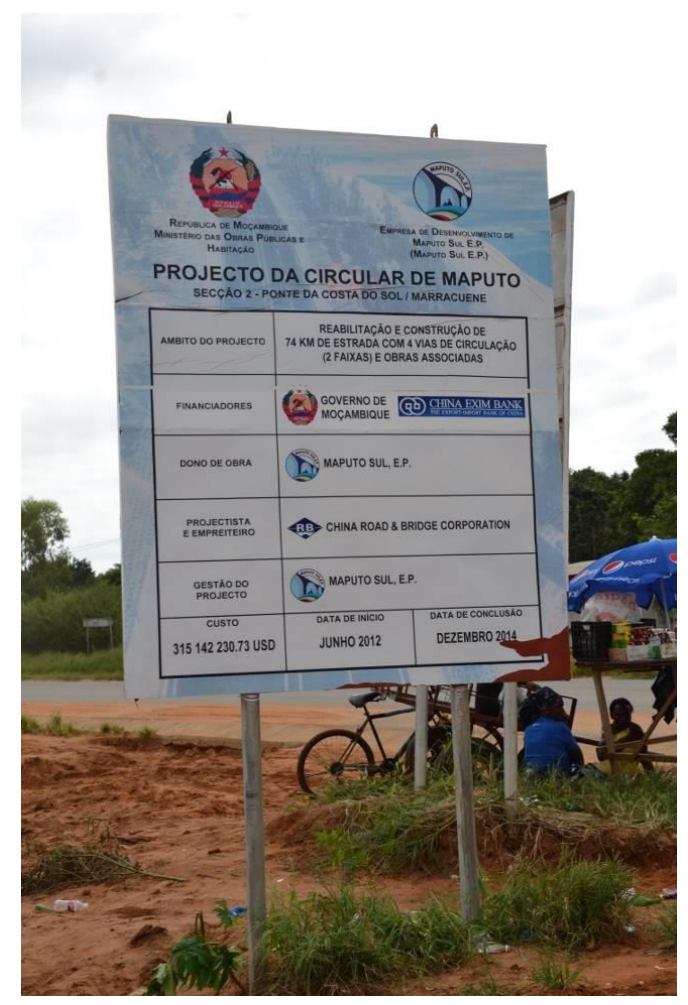

Figura 6: Ponte de acesso à praia de Macaneta Autor: MORETTI, E. C., 2016..

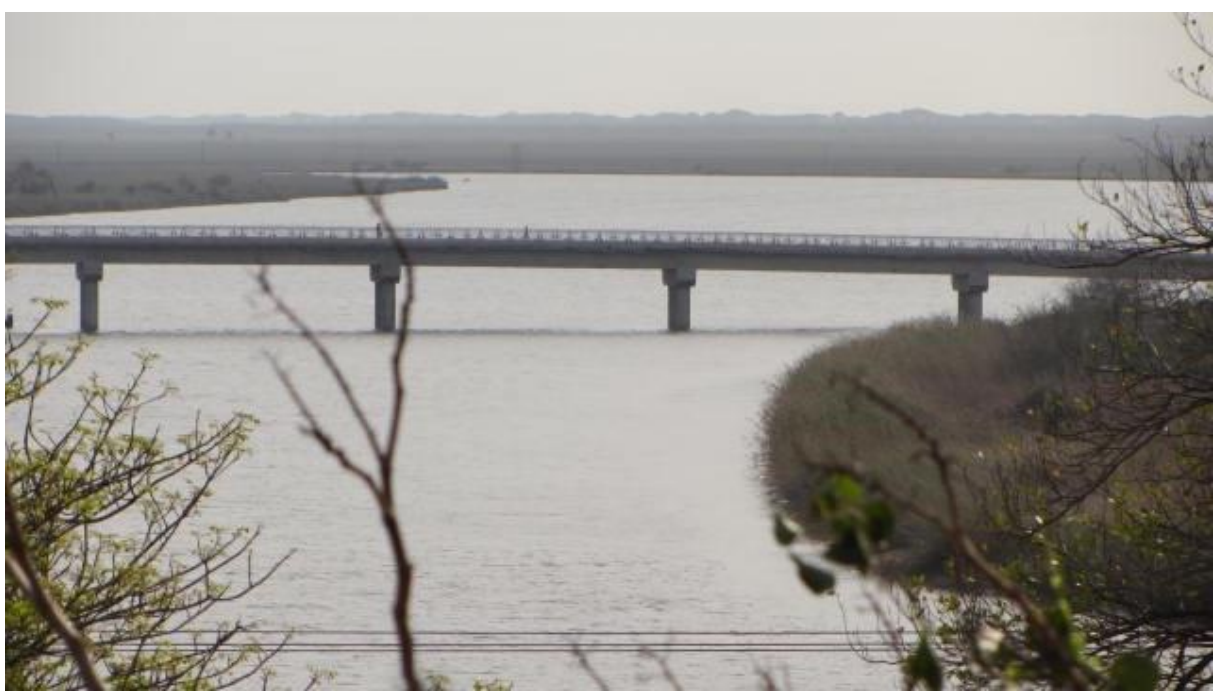


Jornais locais destacam a importância das obras para o turismo de praia, incluindo Marracuene e a praia de Macaneta, como podemos observar a seguir:

\section{Turistas começam a usar estradas de ligação}

Turistas provenientes dos quatro cantos do mundo já estão a utilizar as estradas Boane/Bela Vista e Bela Vista/Ponta D'Ouro como trajeto preferencial para alcançar a província sul-africana de Durban. Efetivamente, começa a ser corriqueiro cruzar-se, por aquelas bandas, com automóveis de matrícula estrangeira, sendo maioritariamente turistas à busca de lazer, e a tendência é aumentar, o que não era muito comum até há poucos meses. (JORNAL DE DOMINGO, 2017, s/p.)

Figura 7. Aspecto da Praia de Macaneta. Barcos de Pescadores. Autor: MORETTI, E. C., 2015.

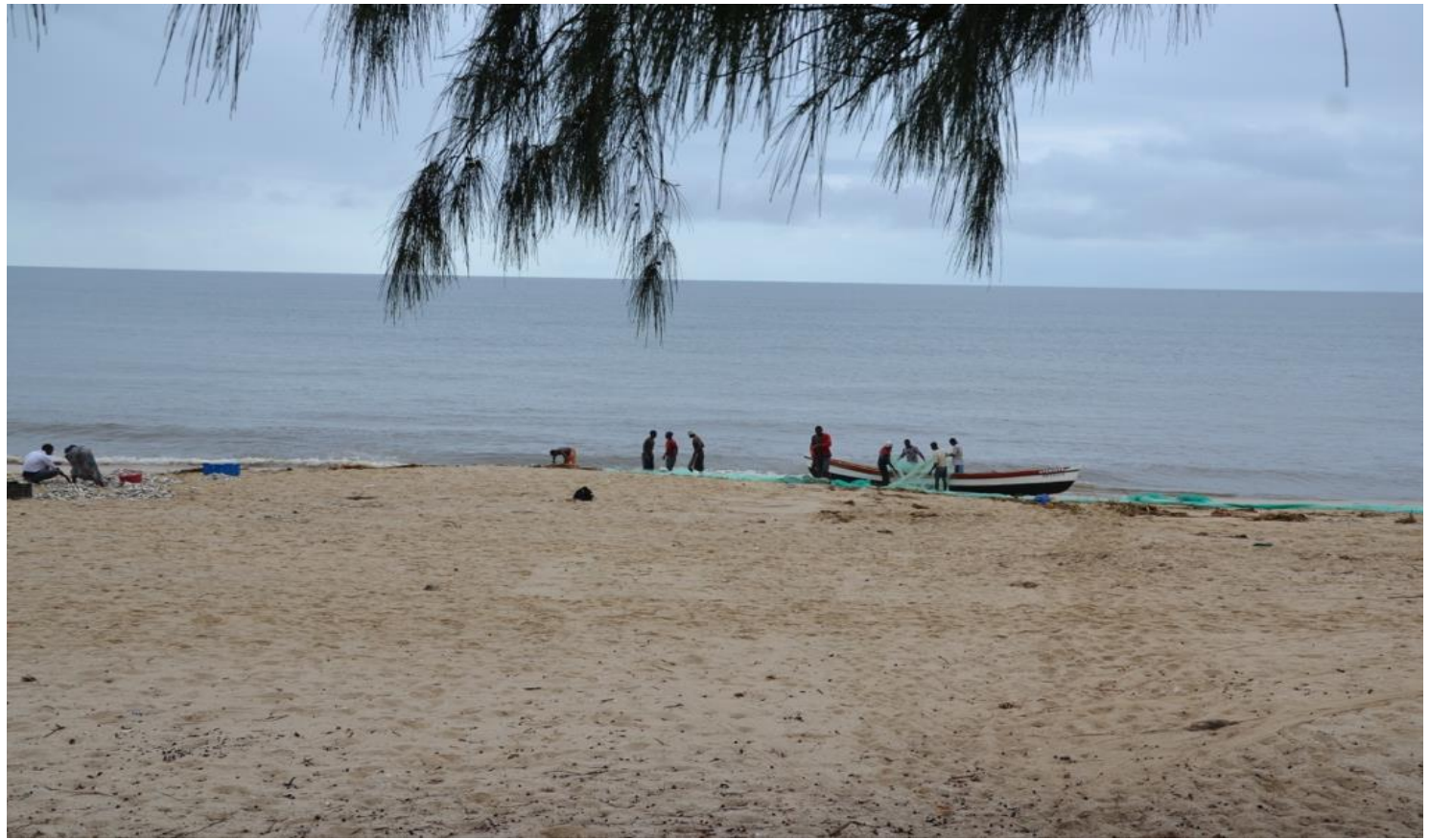

A prática turística na praia de Macaneta está centrada em hotéis, implantados na orla marítima. Os hotéis são as infraestruturas disponíveis para a hospedagem dos turistas além de promoverem a atratividade para esta praia especificamente.

Hotéis

Na praia estão localizados hotéis de diferentes categorias, entre eles destacam: Jays Beach Lodge; Surise Lodge Macaneta; Macaneta Resort; Macaneta Holiday Resort; Lugar do Mar; Tan’n Biki. 
Figura 8. Placas indicativas de hotéis em Macaneta. Autor: MORETTI, E. C., 2014.

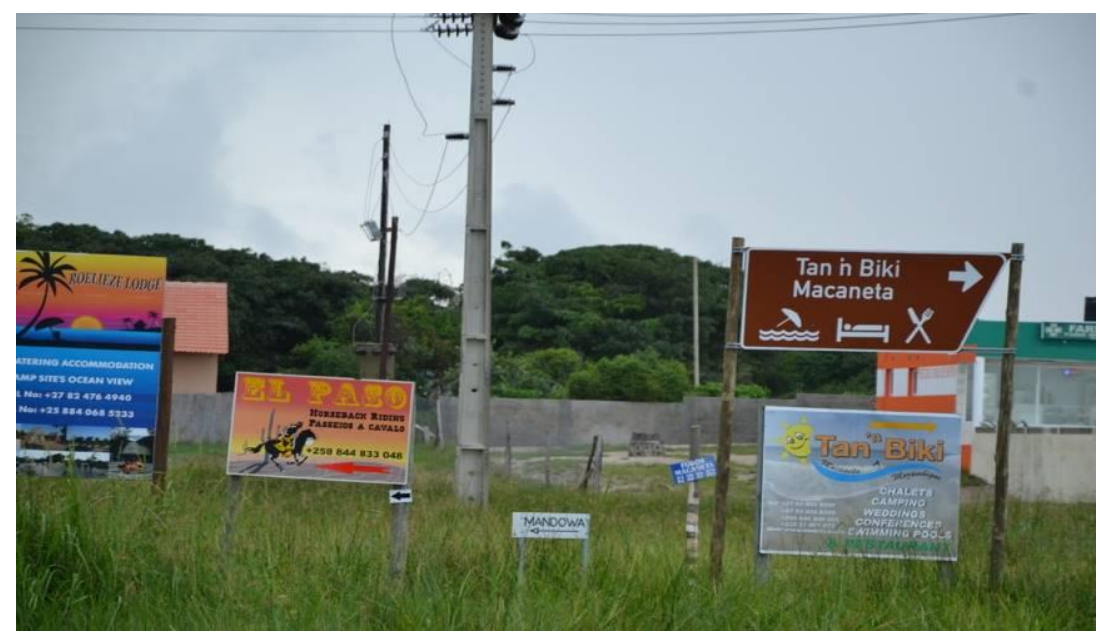

Figura 9. Edificação de hotel em Macaneta. Autor: MORETTI, E. C., 2016.

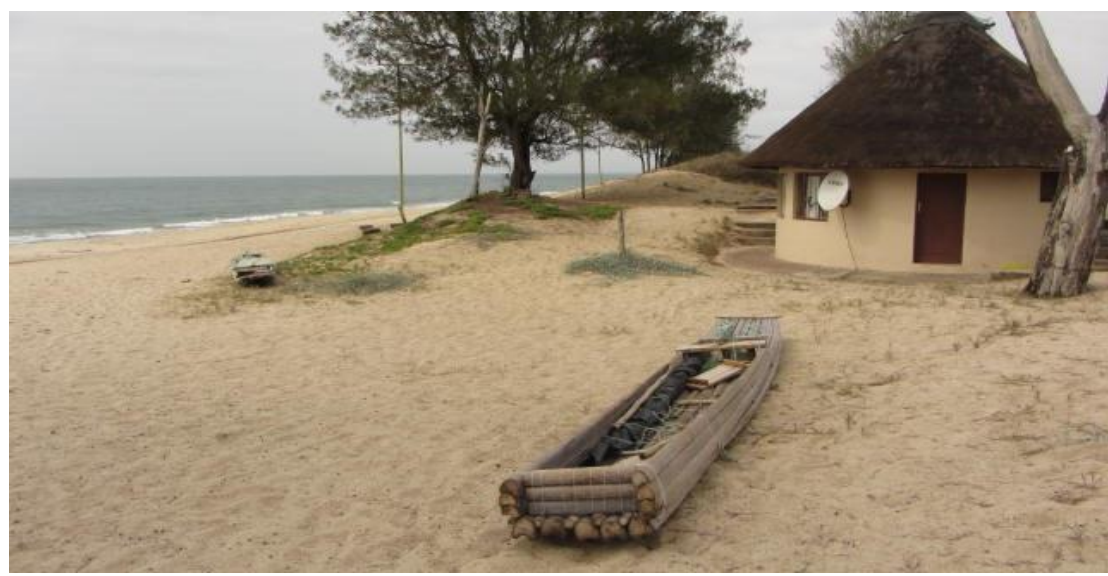

Figura 10. Hotel em Macaneta. Autor: MORETTI, E. C., 2015.

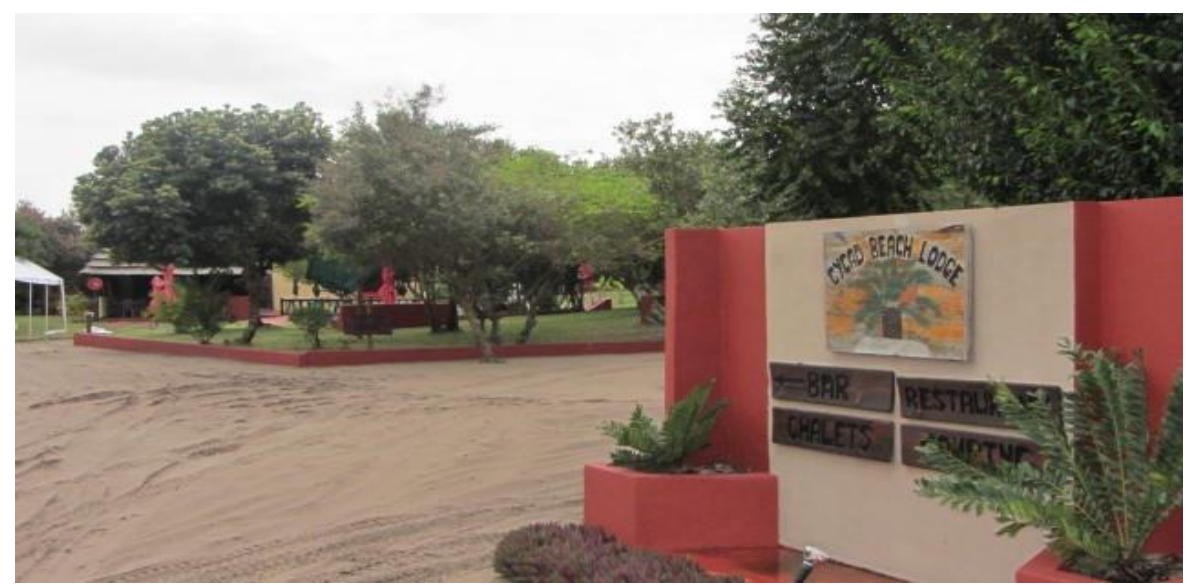


As informações sobre os proprietários destes hotéis são bastante imprecisas, mas, nas entrevistas com trabalhadores e moradores, é indicado que os proprietários são empresários da África do Sul e obtiveram direito de uso da terra para implantação dos hotéis.

Os trabalhadores dos hotéis são contratados de duas formas diferentes, alguns por temporada e outros fixos. Os trabalhadores fixos são em número menor, são mantidos para realizarem a manutenção dos hotéis na baixa temporada. Nos hotéis que realizamos as pesquisas, estavam empregados entre 3 a 5 funcionários fixos para cada hotel, informação prestada de forma informal pelos próprios trabalhadores dos hotéis. Os trabalhadores braçais dos hotéis são moçambicanos (camareiras, atendentes, vigias, serviços gerais de manutenção) os cargos de gerência são destinados a sul-africanos. Infelizmente, não conseguimos informações oficiais sobre o número de trabalhadores dos hotéis em Macaneta, também não foi disponibilizado pelas empresas o quantitativo de trabalhadores por hotel.

Os hotéis atendem preferencialmente turistas sul-africanos, motivados pelo lazer de praia, pesca no mar e mergulho. $\mathrm{O}$ acesso aos hotéis de Macaneta ocorrem via terrestre com veículo adequados para as estradas que passam pelas dunas de Macaneta.

Os hotéis possuem uma baixa relação com a comunidade local do Distrito de Marracuene e da praia de Macaneta. O único produto oriundo do trabalho da população local é o pescado do mar, coletado pelos pescadores locais que fornecem parte dos peixes para os restaurantes dos hotéis.

Algumas ações dos hotéis tem promovido o distanciamento ainda maior dos moradores locais da atividade turística, uma delas, a mais criticada pelos moradores é a implantação de cancelas nas vias de acesso à praia de Macaneta, protegidas por homens armados de forma ostensiva, com a cobrança de taxas para acesso a praia.

Outra ação bastante impopular junto a comunidade são placas indicativas dos hotéis, representação de um homem branco para sinalizar a direção para o hotel. Na relação histórica conflituosa entre o colonizador e os habitantes locais, essa ação é considerada ofensiva, é entendida como informando que o hotel é destinado a homens brancos, como podemos observar na figura 11: 
Figura 11. Indicação de hotéis em Marracuene. Autor: MORETTI, E. C., 2014.

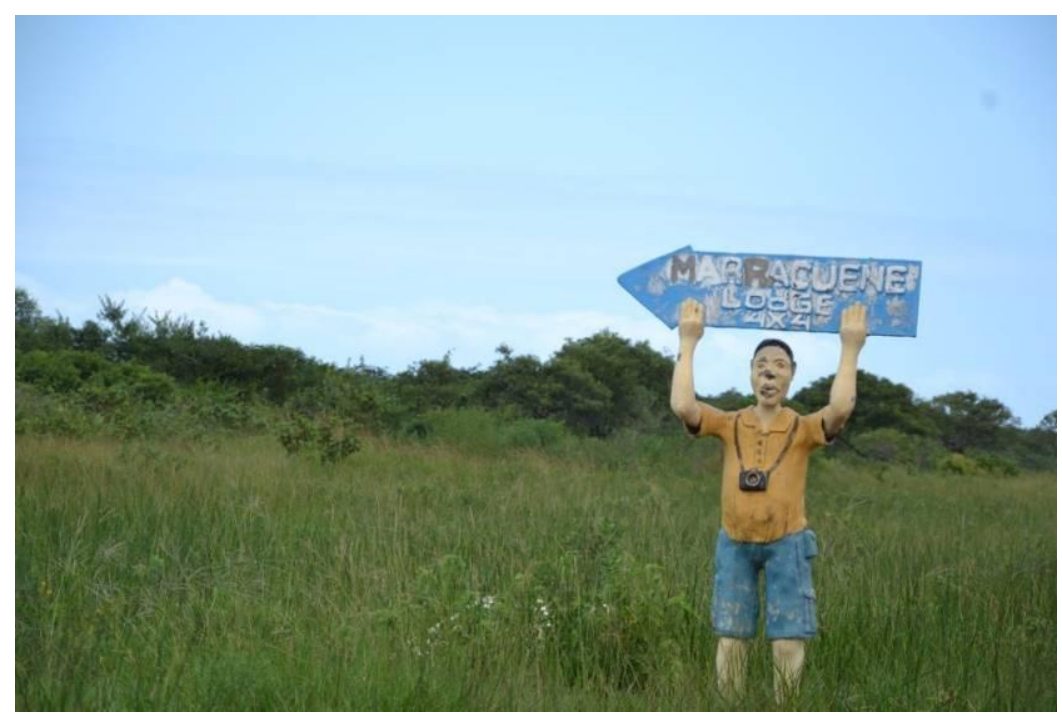

Os hotéis promoveram a implantação de quiosques na praia, que atendem aos turistas, e ao mesmo tempo, comercializam alimentos e bebidas.

Figura 12. Quiosque na Praia de Macaneta. Autor: MORETTI, E. C., 2016.

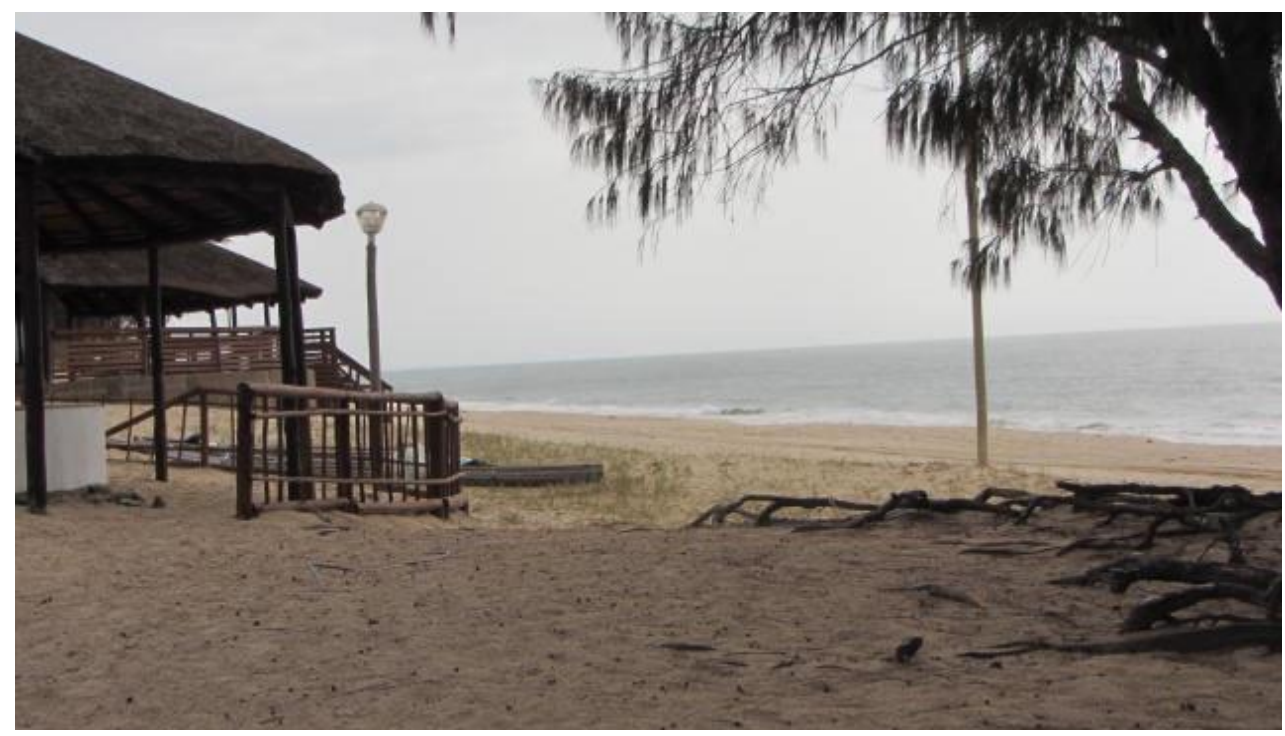

Estes quiosques funcionam apenas no período de concentração de turistas, normalmente durante as férias e feriados prolongados na África do Sul. 
Os hotéis não possuem relação direta com a prática da pesca marítima, desenvolvida por pesadores amadores. Mas, utilizam do pescado destes, para alimentação dos turistas. A paisagem da chegada dos barcos de pesca é um atrativo para os turistas, que nesses momentos deslocam-se até o local de chegada dos barcos, essa paisagem é utilizada pelos hotéis como divulgação do lugar turístico.

Figura 13. Pesca artesanal na Praia de Macaneta. Autor: MORETTI, E. C., 2014.

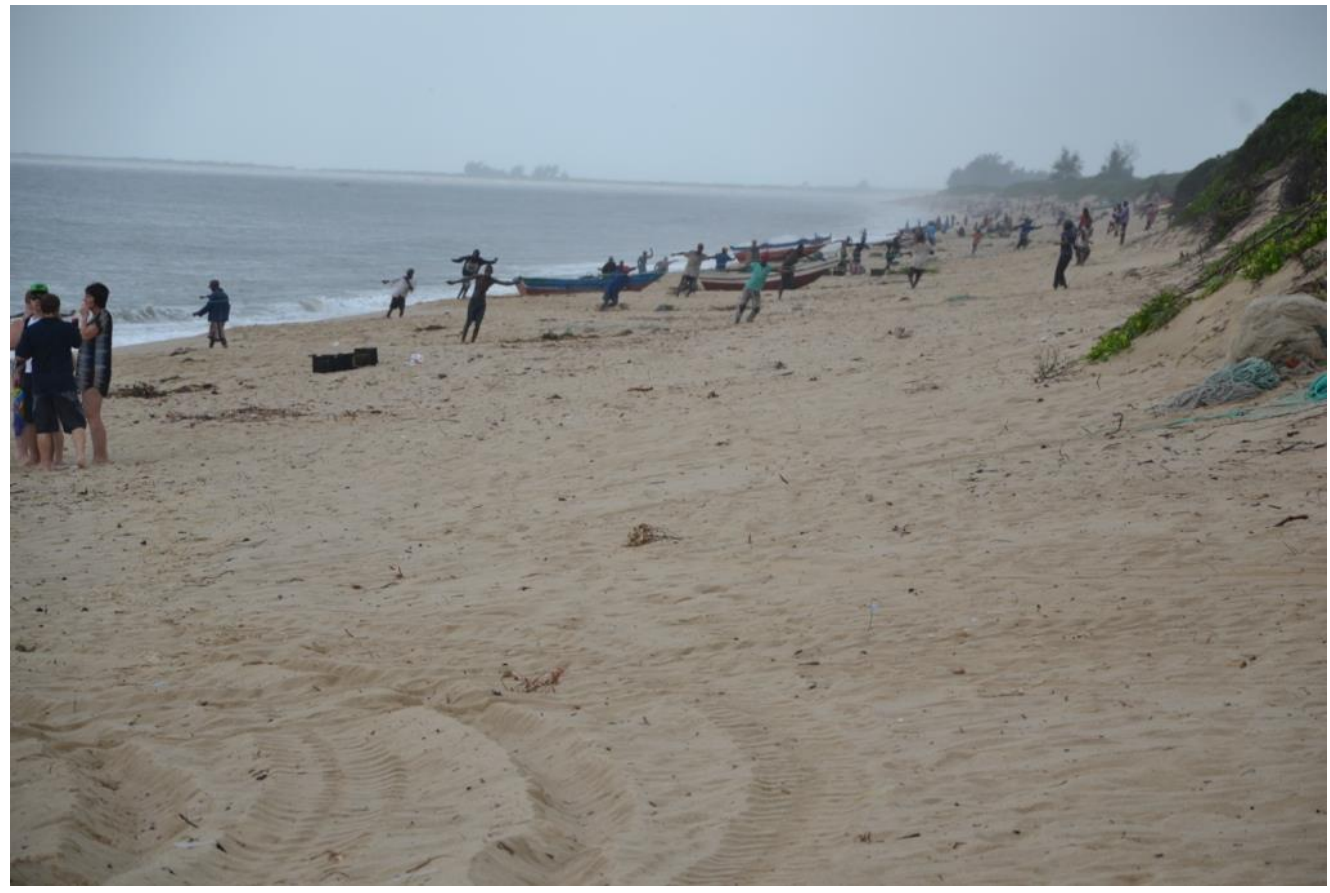

A pesca artesanal representa a maior fatia da produção pesqueira moçambicana. Conforme informado pelo Ministério do Mar, Águas Interiores e Pesca, em seu Balanço Analítico do Plano Econômico e Social, em 2015 foram produzidos pela pesca artesanal 259 mil toneladas de pescado diverso, em termos de valoração registou uma realização de 17449 milhões de meticais.

Quadro 1. Produção da pesca artesanal em Moçambique no ano de 2015. Fonte: Moçambique (2015).

\begin{tabular}{|c|c|}
\hline Produto & Toneladas \\
\hline Lagosta & 116 \\
\hline Caranguejo & 2.894 \\
\hline Peixe Marinho & 162.272 \\
\hline Peixe de água doce & 76.405 \\
\hline Camarão & 5.240 \\
\hline Acetes & 2.462 \\
\hline Cefalópedes & 1.772 \\
\hline Tubarão & 1.298 \\
\hline Outros & 2.638 \\
\hline
\end{tabular}


Dados fornecidos pelo Ministério do Mar, Águas Interiores e Pesca, informam que em Macaneta, atuam cerca de 220 pescadores em cerca de 50 embarcações movidas a remo. As artes de pesca usadas são: linha, emalhar e arrasto. Tem uma produção média por barco de cerca de 200kg (Dados de 2014).

A pesca realizada a partir da Praia de Macaneta ocorre no Canal de Moçambique no Oceano Indico, é realizada por pescadores de Marracuene de forma artesanal, envolve os homens na pesca e mulheres na separação, transporte e comercialização dos peixes. Por ser realizada em barcos a remo a pesca é realizada apenas nas proximidades do litoral, ocorrendo pressão sobre o estoque pesqueiro. Segundo informações coletadas junto aos pescadores locais, eles perceberam que ocorreu diminuição da quantidade de peixes pescados.

Parte do pescado é comercializado para os hotéis, e a outra parte in natura nas feiras locais e nos mercados na cidade de Maputo, parte é salgado para venda futura e mesmo transportado para venda em mercados mais distantes. É comum o uso do pescado para troca, normalmente trocado por alimentos agrícolas produzidos por agricultores no Distrito de Marracuene ou por produtos industrializados - roupas ou alimentos.

Na sequencia de fotos, o processo de coleta do peixe: a chegada de barco de pesca na praia, a retirada das redes de pesca, a separação dos peixes, o armazenamento e o transporte do produto da pesca.

Figura 14. Imagens do desembarque de pescado em Macaneta. Autor: MORETTI, E. C., 2015.

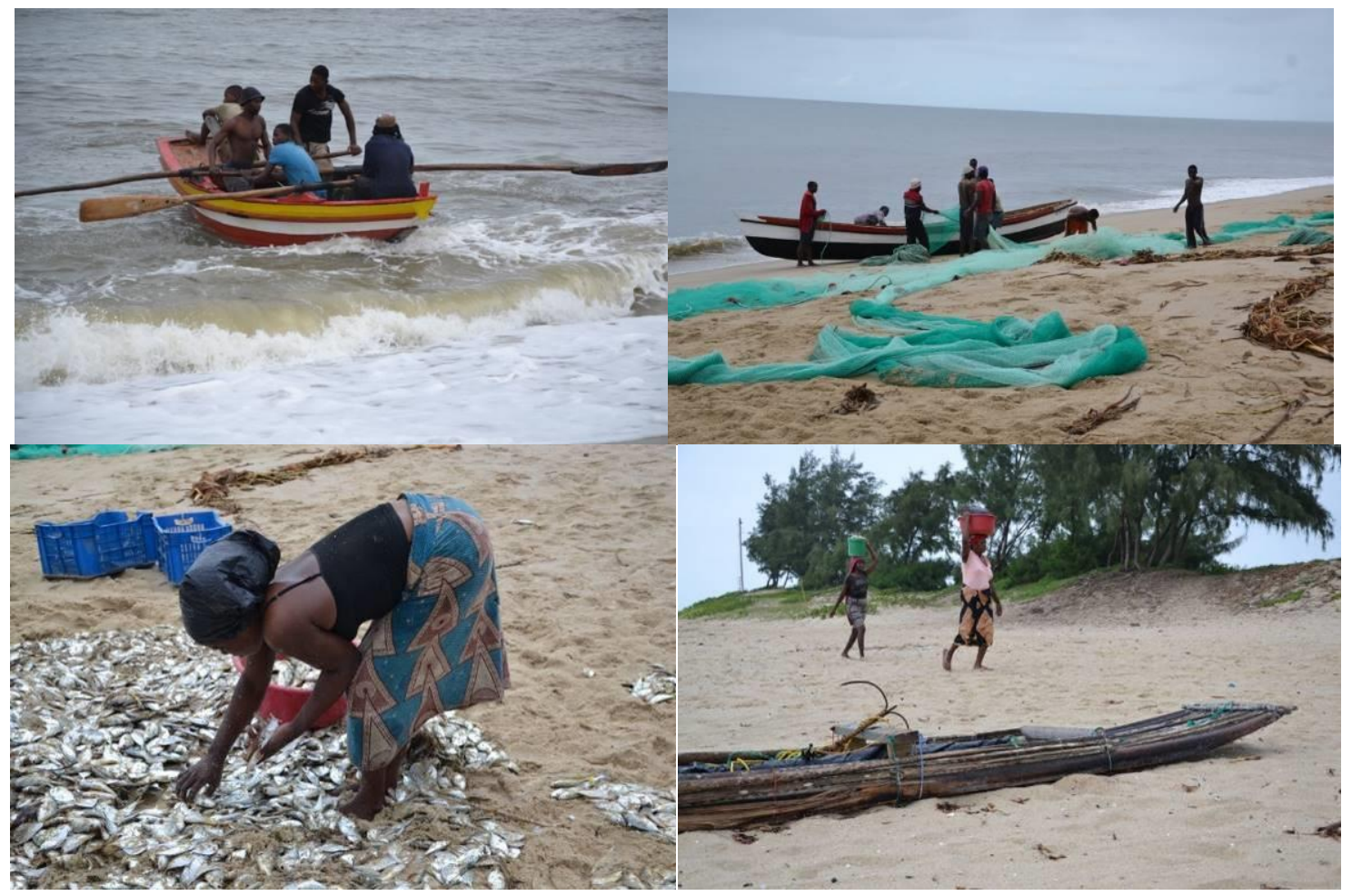


A prática turística na Praia de Macaneta provocou alterações no cotidiano dos pescadores. Nos anos de 2015 e 2016 eles foram retirados de seus lugares tradicionais de desembarque na praia, passaram a atuar em pontos distantes dos hotéis. Segundo os pescadores, essa solicitação foi para afastar eles dos hóspedes dos hotéis que utilizam a praia para banho e atividades variadas de lazer (Entrevistas com pescadores na praia de Macaneta, 2016).

O maior problema gerado foi o aumento da distância a ser percorrida no transporte dos pescados. 0 pescado é transportado por mulheres, que percorrem grandes distancias com os peixes equilibrados na cabeça como podemos observar na figura 14:

Figura 15. Transporte de peixes, praia de Macaneta. Autor: MORETTI, E. C., 2015.

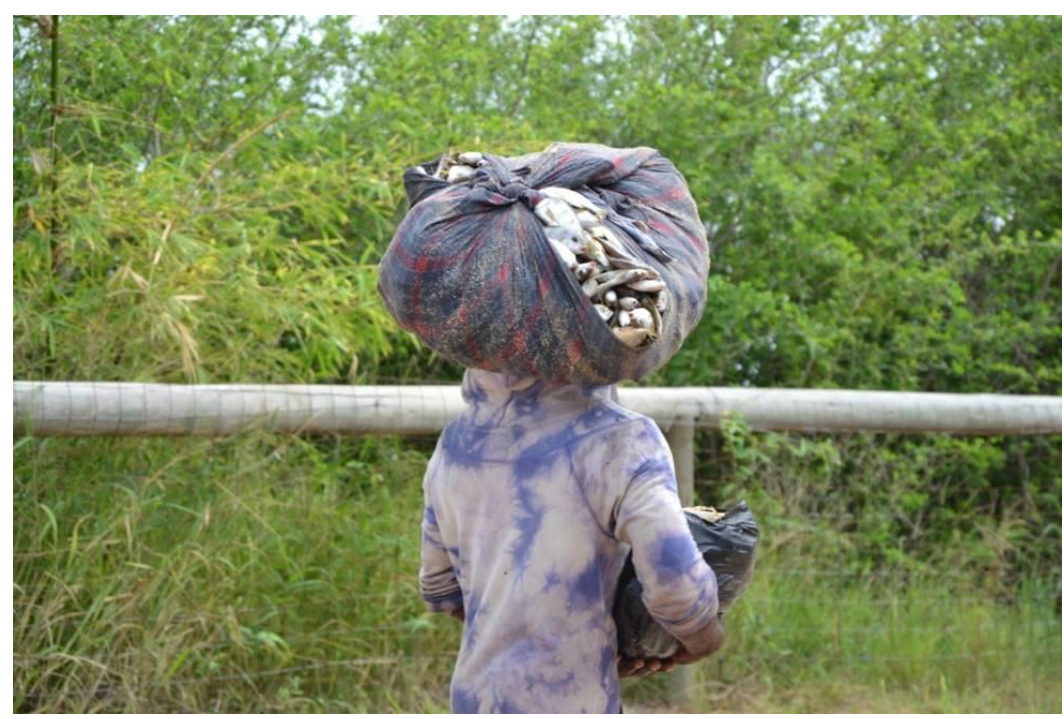

Figura 16. Turistas estrangeiros na praia de Macaneta. Autor: MORETTI, E. C., 2015.

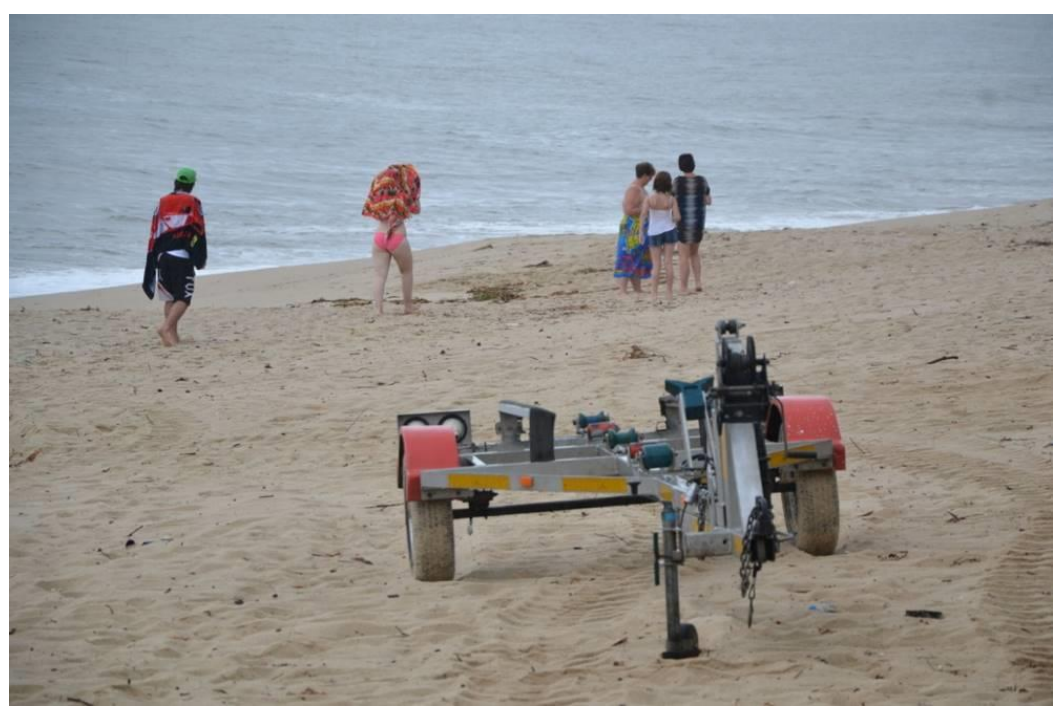


Essas práticas, aliadas a implantação de cancelas nas vias de acesso a praia, fortemente protegidas por homens armados, ocasiona o distanciamento dos moradores locais em relação as atividades turísticas. A produção do lugar turístico afasta os moradores locais de suas práticas, reforça um processo de exclusão social presente na vida cotidiana dos moçambicanos.

O turismo promove a inserção de práticas sociais ao processo de mercantilização da vida, a produção de utensílios culturais são incorporados ao turismo, como objetos desejados. Essa prática, comum e que promove geração de trabalho e renda, está presente nas relações entre o turismo e a comunidade em Marracuene, dois destes objetos foram alvo de nosso olhar, a produção de máscaras e de panelinhas.

Produção de máscaras

As máscaras encontradas à venda em mercados na cidade de Maputo, são produzidas por grupos organizados em oficinas de artesanato sendo reconhecidos como os artesãos de máscaras.

Figura 17. Oficina de produção de artesanato, máscaras. Autor: MORETTI, E. C., 2014.

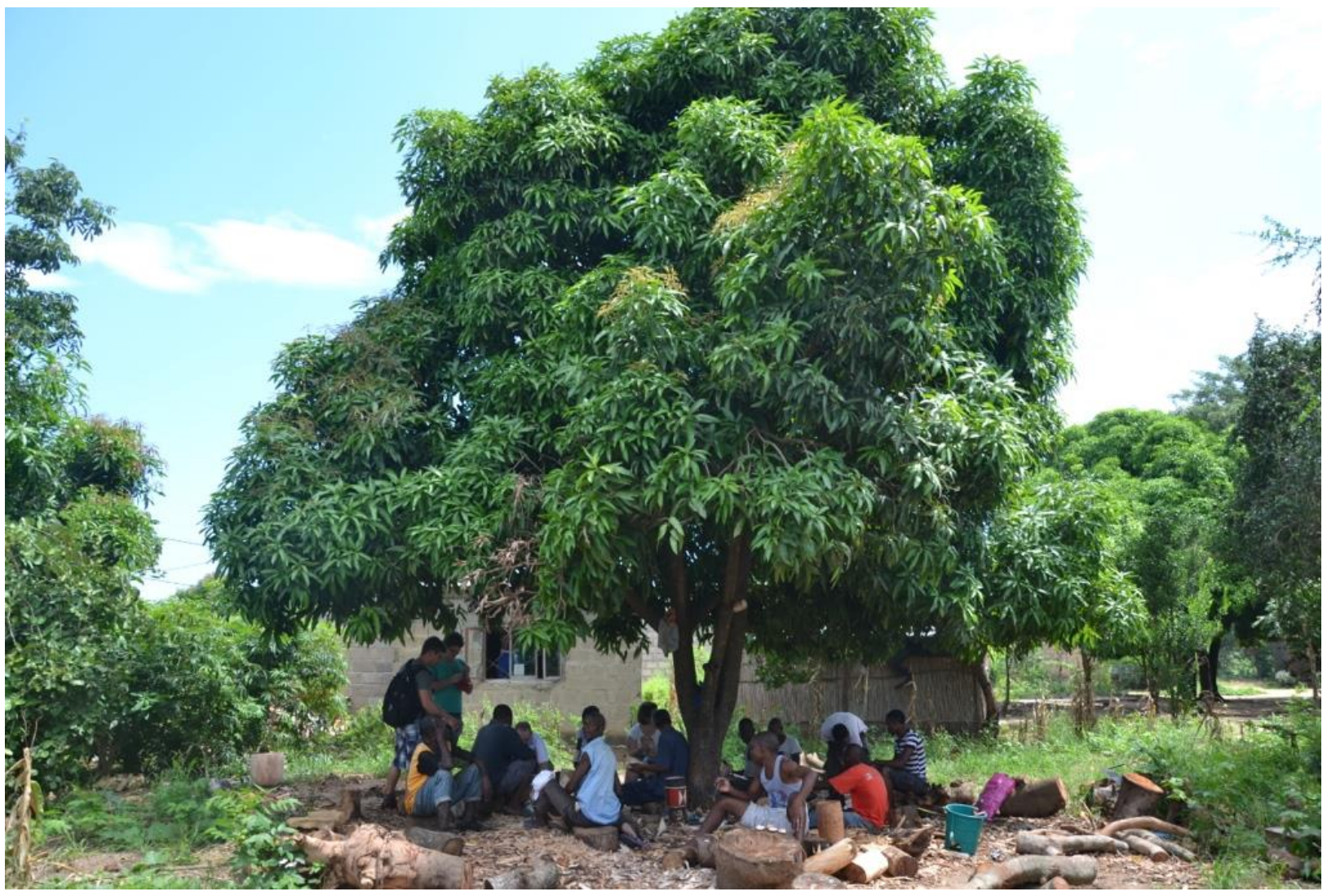


O grupo pesquisado, realiza a atividade em baixo de uma árvore, lugar reconhecido como oficina, cortam coletivamente a árvore através de instrumentos simples (serrotes, machados e facões), a partir de pedaços de madeira produzem peças artesanais, com destaque para as máscaras.

Cada artesão produz uma peça integral, não ocorre divisão do trabalho para produção de uma peça. Cada artesão define o modelo da peça e as cores a serem utilizadas no acabamento, mas existe troca constante de conhecimento e de sugestões para cada peça em produção.

A oficina, conta com a presença de 10 artesões, entre jovens e idosos. Todos homens e moradores do próprio local da oficina e vivem da renda do comércio do artesanato.

A comercialização é feita na própria oficina, normalmente os compradores são comerciantes das feiras de artesanatos localizadas em Maputo, esporadicamente ocorre encomendas de pessoas interessadas nas obras.

Os artesãos não comercializam suas peças diretamente para hotéis, ou outras empresas turísticas. Eles não possuem relação com o turismo, apenas produzem as peças artesanais e as repassam para vendedores que tem acesso aos turistas.

Figura 18. Produção de máscaras na oficina de artesanato. Autor: MORETTI, E. C., 2014.

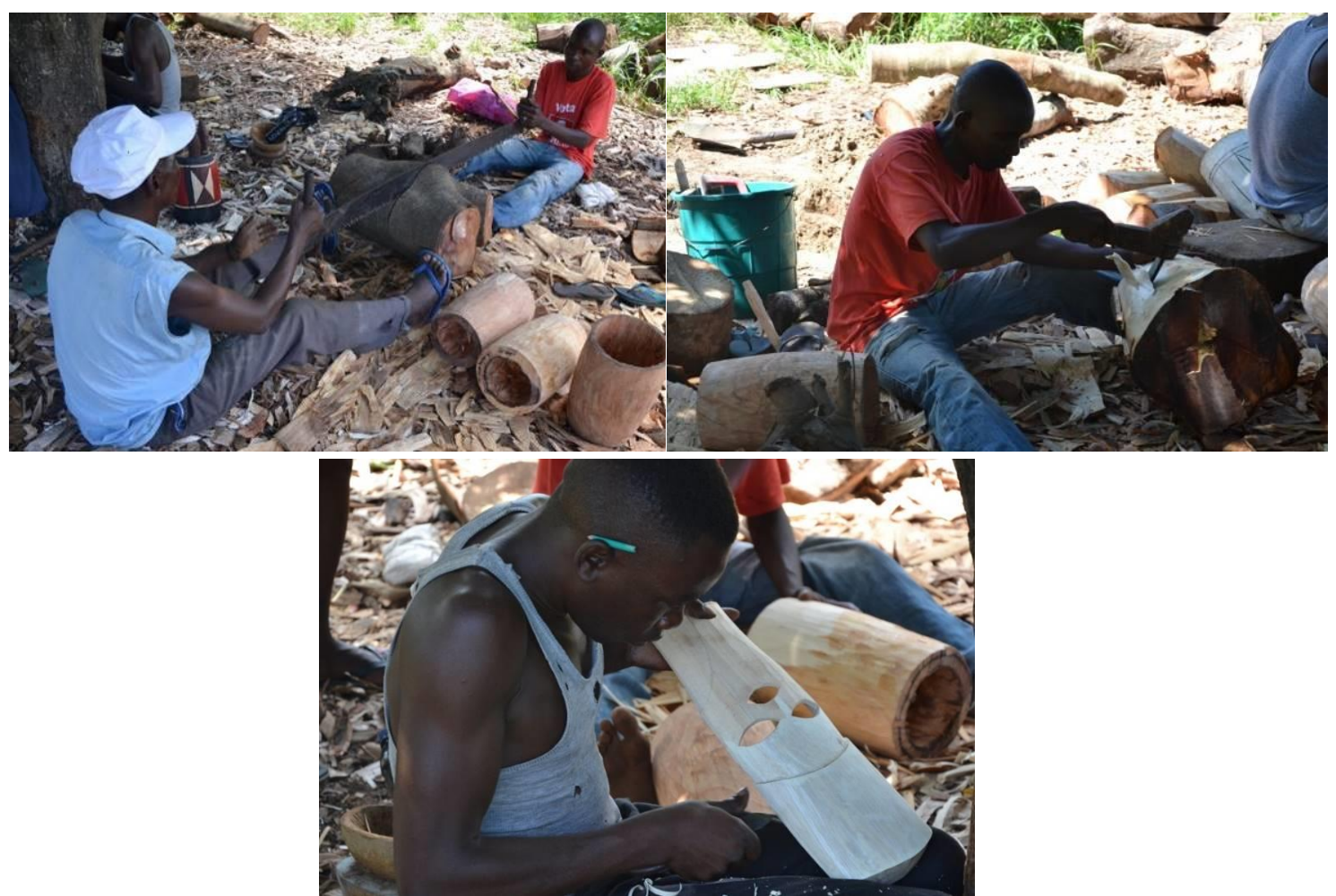


Produção de panelinhas de barro

Na feira de Marracuene e em mercados na cidade de Maputo, observamos a comercialização de panelas de barro, produzidas artesanalmente por mulheres.

As panelinhas de barro são utensílios utilizados para elaborar chás destinados aos recém-nascidos. Existe a crença que as mães devem oferecer os chás para as crianças até completarem um ano de idade, desta forma evitam que a criança fique doente. Por ter esta função cultural as panelinhas de barro são facilmente comercializadas e não tem originalmente o turismo objetivo da produção.

Recentemente, com o incentivo ao turismo, as panelinhas de barro passaram a despertar atenção de turistas e consequentemente são comercializadas nas feiras de artesanato.

As panelinhas de barro são produzidas no campo, por mulheres, normalmente nas próprias terras onde moram, em áreas de fácil acesso a matéria-prima destinada a produção. Não existe organização de mulheres produtoras das panelinhas, e a comercialização nas feiras é feita diretamente pelas mulheres produtoras ou membros da família. Nos centros de comércio para os turistas as panelinhas são vendidas pelos comerciantes que compram o produto das mulheres produtoras.

A produção das panelinhas é artesanal, não envolve nenhum equipamento ou máquina, somente as mãos. Após a produção as panelinhas são colocadas para secar de forma natural e armazenadas na própria casa das mulheres produtoras.

Figura 19. Produção de panelinhas de barros realizada por artesã de Marracuene. Autor: MORETTI, E. C., 2014.

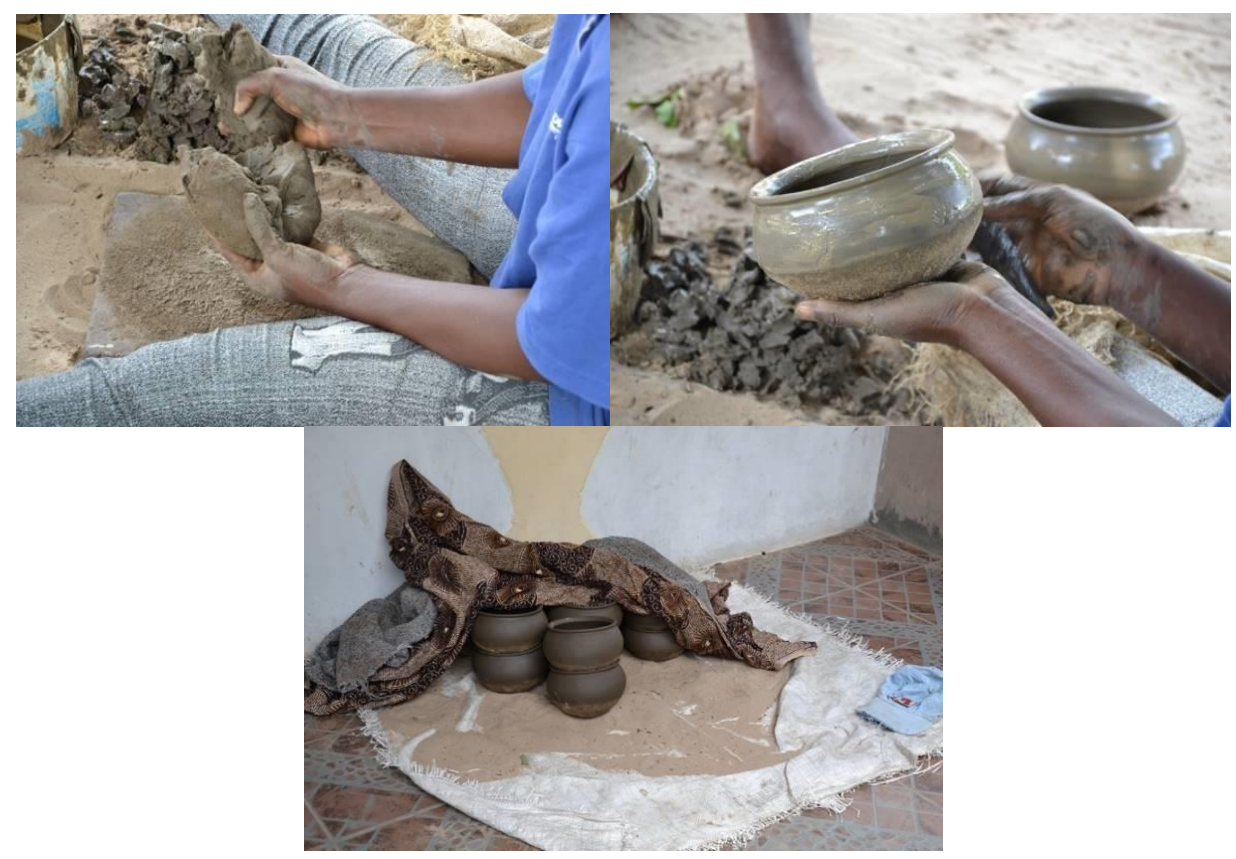


A técnica de produção de máscaras e de panelinhas, foram repassadas por membros da própria família, constituindo em uma atividade familiar em sua essência.

A comercialização ocorre nas feiras comunitárias e nas feiras destinadas aos turistas em Maputo. A comercialização nos mercados turísticos é realizada por atravessadores, possuidores de acesso a estes mercados, seja como fornecedores para vendedores com pontos nos mercados, seja, como vendedores direto nas feiras de rua que atendem turistas.

\section{CONSIDERAÇÕES FINAIS}

Os levantamentos de campo apontam para olhares além das falas, discursos e planos do Governo Moçambicano, que muitas vezes estão enquadrados nos projetos internacionais de financiamento e distantes das realidades locais.

Ocorre um distanciamento fenomenal entre a implantação de equipamentos para o turismo, vias de acesso, pontes, hotéis, marinas, orlas, propaganda e a população moçambicana. $O$ trabalho no turismo é realizado de forma informal, sem garantia de continuidade. Ocorre profunda distinção entre os trabalhos masculinos e femininos, para as mulheres cabem papéis no processo de trabalho nem sempre de acordo com o que elas desejam.

A incorporação ao turismo das práticas sociais e culturais de produção de bens locais é incipiente, feita de forma coletiva na produção, mas individualizada na comercialização, promovendo o distanciamento do produtor artesão do resultado do fruto de seu trabalho, transformado em uma mercadoria sem conteúdo nas feiras.

Concretamente podem ser apresentadas propostas que partem de algumas ações que consideramos urgentes para inserção dos trabalhadores no controle da gestão da prática turística, com a produção de um lugar no sentido de pertencer aos sujeitos que o produzem. Para tanto é fundamental:

- Organização social em torno do tema turismo, com participação direta de trabalhadores do turismo, produtores de artesanato e de utensílios que podem serem valorizados como artesanato;

- Trabalhar no sentido de "empoderar" os produtores e trabalhadores locais para o controle da prática turística, construindo formas de mediação entre os interesses das grande empresas e das comunidades;

- Apoiar e implementar práticas que melhorem as condições de trabalho da população produtora de utensílios artesanais no sentido de valorizar esse trabalho; 
- Pautar a implantação de organização social no sentido de controle do comércio dos produtos artesanais, com preocupação em ampliar as possibilidades de inserção dos produtos produzidos artesanalmente em todos os lugares destinados ao turismo.

As ações foram pensadas a partir das reflexões do cotidiano vivenciado pelas pessoas entrevistadas, seus sonhos, desafios e capacidade de resistir. Mas, é claro que não é possível tratar o turismo como uma atividade separada dos processos sociais, políticos, culturais e econômicos vividos pela população. Portanto, o avanço da possibilidade de implementar o turismo na sua forma comunitária, esta atrelada ao direcionamento político definido pela nação.

O turismo, na perspectiva de prática social, precisa ser analisado e proposto participando das questões sociais, politicas, econômicas, culturais e ambientais, que se apresentam para os povos. Foi nesse sentido que desenvolvemos as atividades de pesquisa, procurando dar significados para nossas inquietações, e gerando possibilidades de contribuir para a reflexão sobre os caminhos a serem trilhados.

Para o desenvolvimento do turismo comunitário, como uma atividade realizada por meio de um trabalho digno que gere renda compatível às necessidades das pessoas, em primeiro lugar as pessoas devem dizer o que pensam, querem e sabem fazer; segundo é fundamental ponderar sobre a realidade do país, como as comunidades viviam e vivem, seus saberes e fazeres, a cultura com suas permanências e mudanças, dentre outros matizes do cotidiano.

Finalizo as reflexões sobre turismo comunitário e produção de geografias em Moçambique, com as palavras de Ricardo Ossagô de Carvalho,

“É importante ressaltar que a resistência dos povos em defender seus territórios, suas culturas e sua visão de mundo, não se mede pelo sucesso qualitativo ou quantitativo obtido. Ela se mede, apesar dos momentos de derrotas e glórias, pelo simples fato de defender a dignidade e a liberdade humana quando estas são ameaçadas." (CARVALHO, 2014, p. 16)

\section{REFERÊNCIAS}

CARVALHO, Ricardo Ossagô de. O entendimento da África e o Brasil africano. Revista. Publicação Semana da África na UFRGS. v.1 n. 1. Maio 2014.

JORNAL DE DOMINGO. Turistas começam a usar a estrada de ligação. Disponível em: <www.jornaldomingo.co.mz>. Acesso em: 23/04/2017.

MARTINS, José de Souza. Sociologia da Fotografia e da Imagem. São Paulo: Editora Contexto, 2008.

MOÇAMBIQUE. Direito do Uso e Aproveitamento de Terra. 2015. Portal do Governo de Moçambique. Disponível em: http://www.portaldogoverno.gov.mz/por/Cidadao/Informacao /Direito-do-Uso-eAproveitamento-de-Terra. Acesso em: 11/11/2016 às $18 \mathrm{~h} 24 \mathrm{~min}$.

MOÇAMBIQUE. Ministério do Mar, Águas Interiores e Pesca. Balanço Análitico do Plano econômico e social - 2015. Maputo. Março de 2016.

SAMPAIO, Carlos Alberto Cioce; ZAMIGNAN, Gabriela. Estudo a Demanda Turística: Experiência de Turismo Comunitário da Microbacia do Rio Sagrado, Morretes (PR). Revista CULTUR. Ano 06. n. 1, fev. 2012. 